\title{
SERBIAN ARMED FORCES RIFLE PLATOON: BASIC MODELS OF COMMAND ORGANISATION
}

\author{
Vinko ŽNIDARŠIČ, Ivan STOJADINOVIĆ, Veljković SLAĐAN \\ University of Defence, Belgrade, Republic of Serbia \\ vinko.znidarsic@va.mod.gov.rs, ivan80stojadinovic@gmail.com
}

\begin{abstract}
This paper is intended for military officers on rifle platoon commander duty to help them in decision making about platoon command organization. Management and command in Serbian Armed Forces rifle platoon are mostly based on experiences of twenty century. Contemporary environment influence on missions of armed forces and surely influence on tactics. To be able to perform given tasks rifle platoon commanders must know how to adopt platoon organisation as a system of sections. This paper gives better understanding how rifle platoon commander could organise subordinated units depending on various duties and weapon systems.
\end{abstract}

Keywords: management and command, command organisation, subordination, infantry, rifle platoon and sections

\section{Introduction}

Researching management and command in Serbian Armed Forces rifle platoons it was observed that on that level commanders need a clear view and possibilities of command organisation. Platoon commanders usually put in practice one model. But regulations allow organizing by the situation.

The research problem has been defined as an organisation of command in a rifle platoon. The hypothesis was that the organisation of command is changeable according to circumstances and the need to perform a specific task. The research aim was set to collect, record and classify all models of command organisations.

\section{Command organization in the rifle platoon}

The rifle platoon is an integral part of an infantry company, and only in special cases rifle platoon work as an independent unit.
The rifle platoon consists of three rifle sections and one machine-gun section (Figure 1).

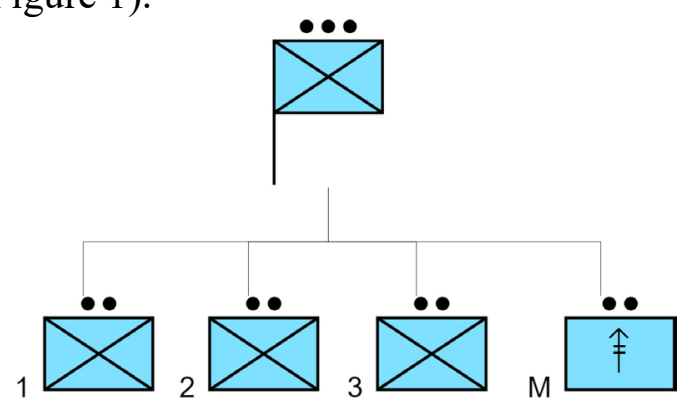

Figure 1: Rifle platoon organizational structure Source: $\mathrm{Kz} O \mathrm{O}$ Ğ VS, Pravilo pešadijska četavod, 2016, Sheme 2

In the rifle platoon senior officer is the platoon commander. Subordinated to rifle platoon commander are (rifle and machinegun) section commanders. Subordinated to sections commanders are soldiers, and that is generally common knowledge of all commander, but the organization of command in the rifle platoon is adaptable to 
the tasks and conditions in which they are performed [1].

In rifle platoon solder duties are: the rifle platoon commander (КВ, "командир вода"), rifle section commander (КО, "командир одељења"), group commander (КГ, "командир групе"), machine-gunner1 (Н-1, "први нишанџија"), assistant machine-gunner-1 (По-1, "помоћник првог нишанџије"), ammunition carrier-2 (Дн-2, "доносилац муниције"), sniper (Сн, "снајпериста"), rifleman-1 (C-1, "први стрелац") [2].

Platoon weapon systems are rifle gun (M70 $7,62 \mathrm{~mm}$ or M21 5,56 mm), sniper rifle (M76 7,9 mm), machine-gun M84 7,62 $\mathrm{mm}$, hand grenades and rocket launchers.

Command in the Serbian Armed Forces is based on the authority and responsibility of the person who is given the right to command for efficient and effective planning of use, organization, ordering, coordination and control of assigned resources during the execution of missions and tasks [1].

By transferring the authority of command to the subordinate commanders, the section and platoon commanders convey the confidence that they will perform the task, but also the obligation to take responsibility if something goes wrong [3] [4].

\section{Rifle platoon command organisation models}

The research began with an analysis of rules and regulations, observing and classifying data which led to the several command organisations models. Those models are complemented by interviews conducted with platoon and company commanders from several Serbian Armed Forces infantry units in 2021.

A basic model is classified in a group of models 1. Models 2 and 3 are been prepared for publishing in other scientific papers.

Experimenting with scenarios they are classified into four subgroups: 1.1, 1.2, 1.3 and 1.4. Each subgroup had two or three under subgroups.

\subsection{Subgroup of models 1.1}

In this subgroup rifle platoon commander is senior to all rifle sections commanders, and rifle sections commanders are senior to all soldiers and light machine-gun crews, and machine-gun section commander is senior to machine-gun crews [5].

The subgroup of models 1.1 consists of two subset models 1.1.1 and 1.1.2 (Figure 2).
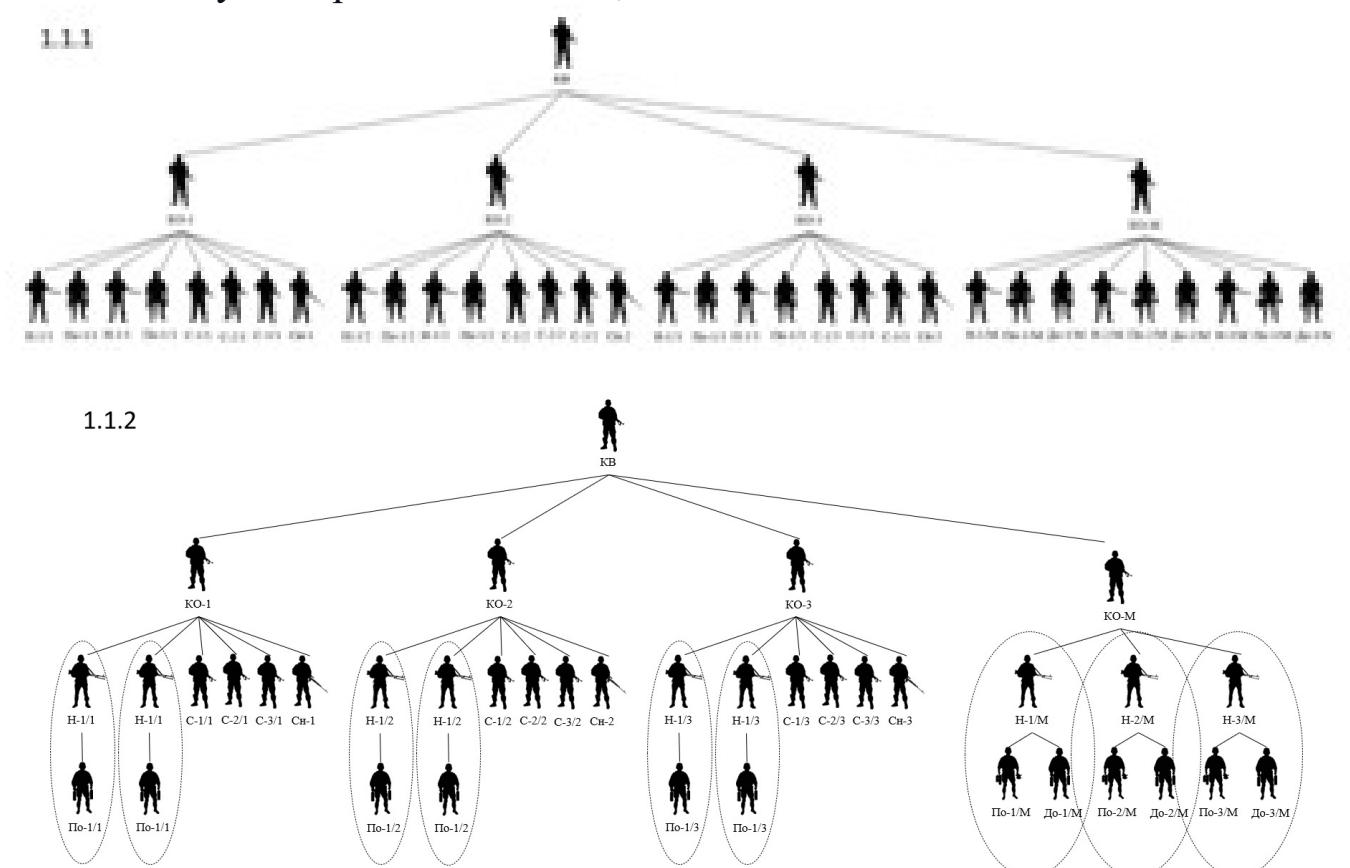

Figure 2: Model of rifle platoon subordination when all soldiers in sections are directly connected to section commanders 


\section{MODEL 1.1.1}

In this and every other basic model rifle platoon commander is senior to the three rifle- and one machine-gun section commander.

In the second line of command, three rifle sections commanders and one machine-gun section commander are senior to solders in sections.

This is the most common perception of relationships in a rifle platoon. Despite it is not practical in combat situations this model is common in use when rifle platoon performs non-combat missions and tasks.

\section{MODEL 1.1.2}

Rifle sections commanders are senior to all soldiers in direct line except with assistant light machine-gunner.

Light machine-gun crew is two men crew. Light machine-gunner is subordinated to rifle section commander and senior to assistant light machine-gunner [6].

Machine-gun section commander is senior to three machine-gun crews.

Machine-gunner is subordinated to machine-gun section commander and senior to assistant machine-gunner and ammunition carrier [7].

This model is more combat situation oriented but section commanders have heavy burden commanding with all soldiers in that way. That is the reason why they divide soldiers into the groups and crews.

Following that observation, next subgroups of models are been created.

Combining the results from previous researches presented in science papers "Analysis of prescribed models of subordination in the Serbian Armed Forces firing section"[8], "Models of subordination in the Serbian Armed Forces rifle section" [9], and interviews with commanders, formed subgroup of models 1.2, 1.3 and 1.4 .

\subsection{SUBGROUP OF MODELS 1.2}

In this subgroup of models each of three rifle sections is divided into three groups of three soldiers. Machine-gun section is divided to three machine-gun crews and that is standard for other basic models (Figure 2). Commanders are senior to group commanders, and group commanders are senior to other soldiers in their group. At the head of these groups, soldiers as group commanders are assigned to delegate some of section commander responsibilities.

Subgroup of models 1.2 consists of two subset models 1.2.1 and 1.2.2 (Figure 3).

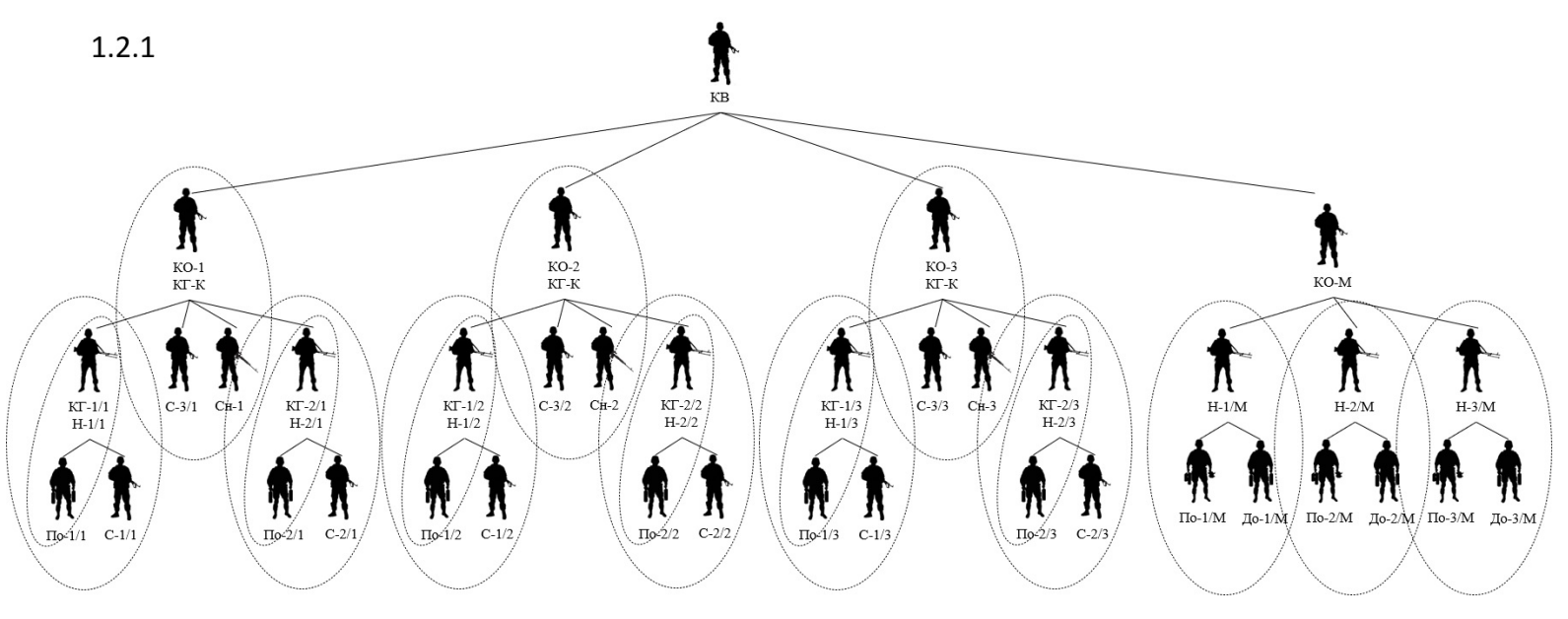




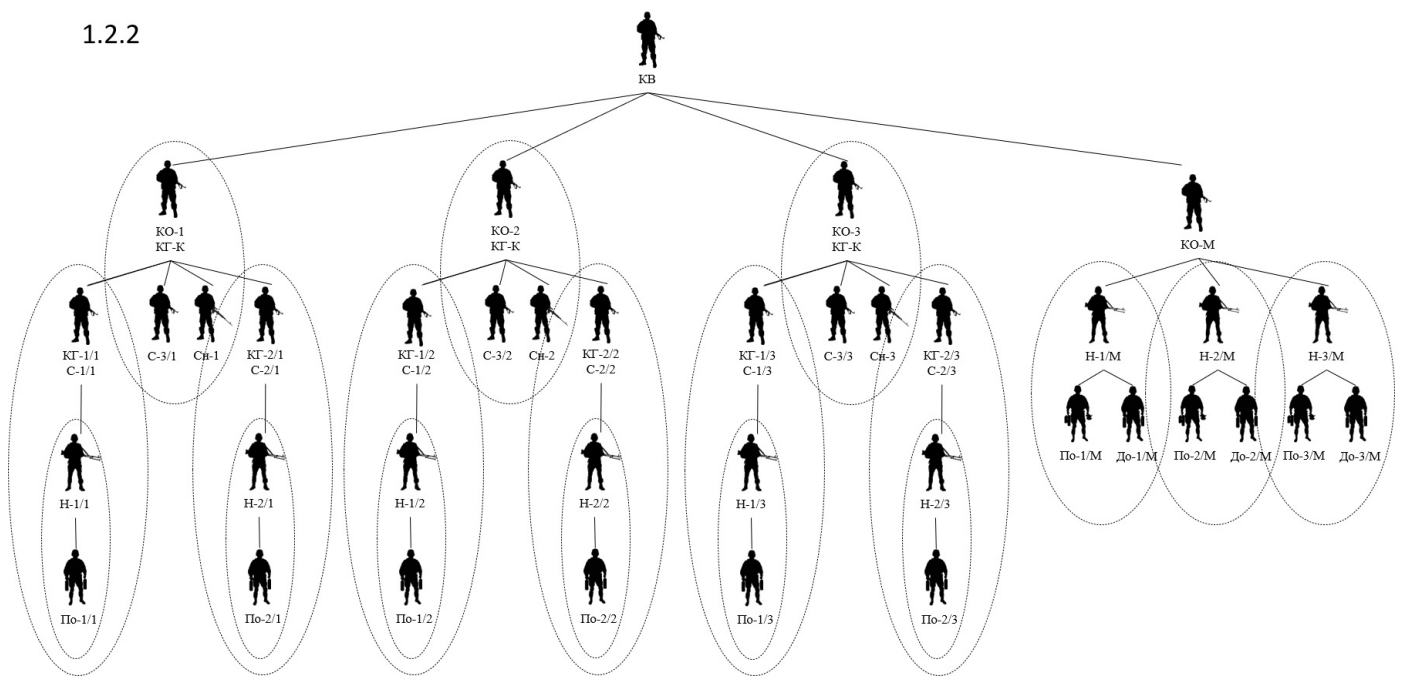

Figure 3: Model 1.2.1 and Model 1.2.2

MODEL 1.2.1

In three rifle sections commanders are senior to two soldiers and two groups. Group commanders in rifle sections are light machine-gunners. Machine-gun section commander is senior to three machine-gun crews.

Those groups in rifle sections have structurally similar organisation as machine-gun crews. Basically, in this model, the rifle platoon consists of nine machine crews and three section command groups.

\section{MODEL 1.2.2}

Retaining the same organization as in model 1.2.1 but replacing the machinegunner with rifleman in the position of group commander, subgroup 1.2.2 was formed.

In this model rifle sections are less effective because groups commanders pass orders from the section commander to the machine-gun crew. This organisation could be effective in defence situation on a wide front.

\subsection{SUBGROUP OF MODELS 1.3}

This model is closer to the model applied by NATO [10] because rifle sections are divided into two groups (in other words: fire-teams) of four soldiers. Machine-gun section commander is senior to three machine-gun crews.

The subgroup of models 1.3 consists of two subset models 1.3.1 and 1.3.2 (Figure 4).

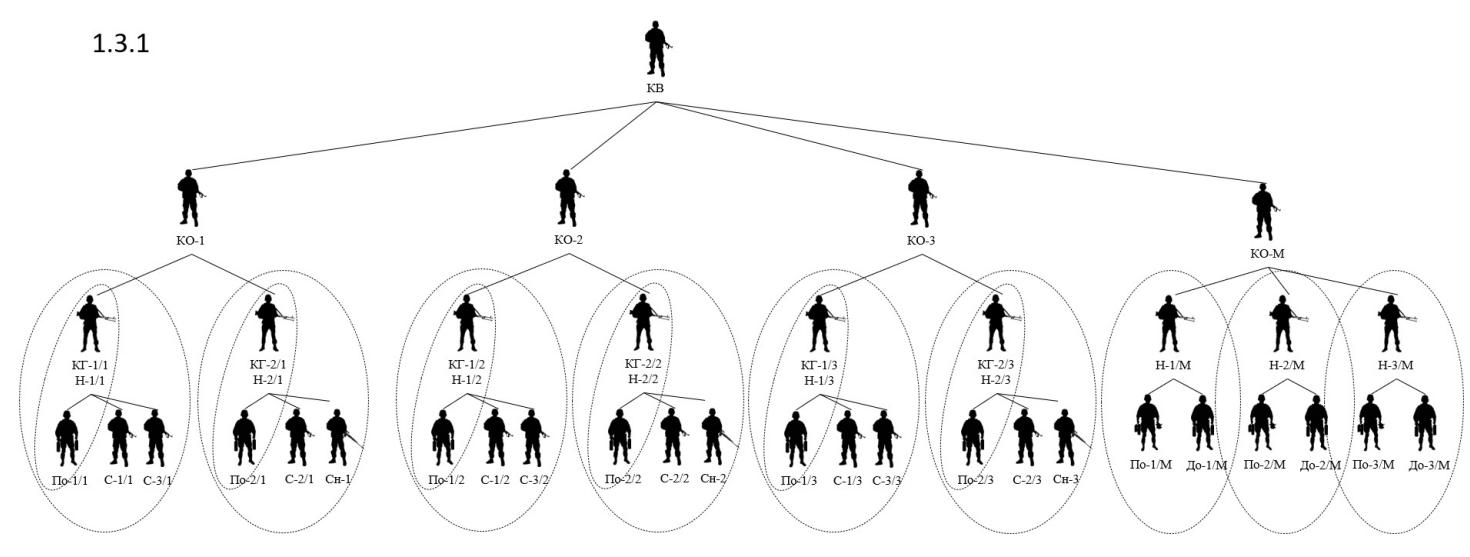




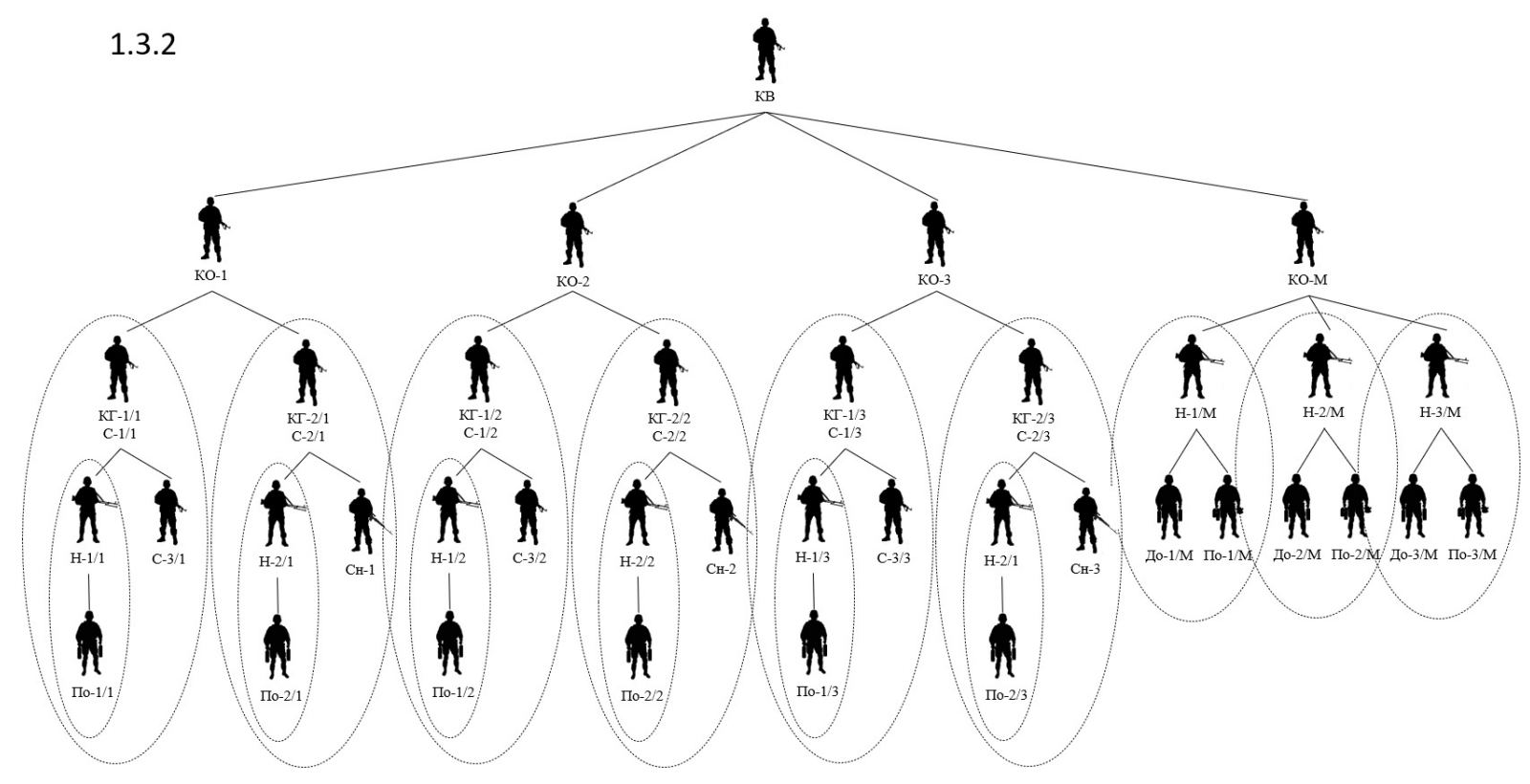

Figure 4: Model 1.3.1 and Model 1.3.2

\section{MODEL 1.3.1}

In this model, three rifle section commanders are senior to two groups of four soldiers. Group commanders are light machine-gunners. Machine-gun section commander is senior to three machine-gun crews.

In this model, it was obvious that light machine-gunners are commanders with too many obligations. In addition to solving fire tasks with an assistant, they have to lead another two soldiers.

\section{MODEL 1.3.2}

With the same organisation as in model 1.3.1 on the position of group commander, the light machine-gunner is replaced with a rifleman.

This supposed to much better effect than in previous models because rifle sections are better balanced with this organisation. Group commanders are in real opportunities to receive orders from the section commander and give orders to the subordinated soldiers and light machinegun crew.

This organisation could be effective in most situations.

Most important for this model is that rifle and machine-gun section commanders get relief and the opportunity to receive and follow platoon commander orders. They also get an opportunity to better lead the sections.

\subsection{SUBGROUP OF MODELS 1.4}

This subgroup of models is a combination and compromise between subgroups of models 1.2 and 1.3. Rifle sections are divided into three groups of two, three and four soldiers. Machine-gun section commander is senior to three machine-gun crews.

The subgroup of models 1.4 consists of three subset models 1.4.1, 1.4.2 and 1.4.3 (Figure 5). 


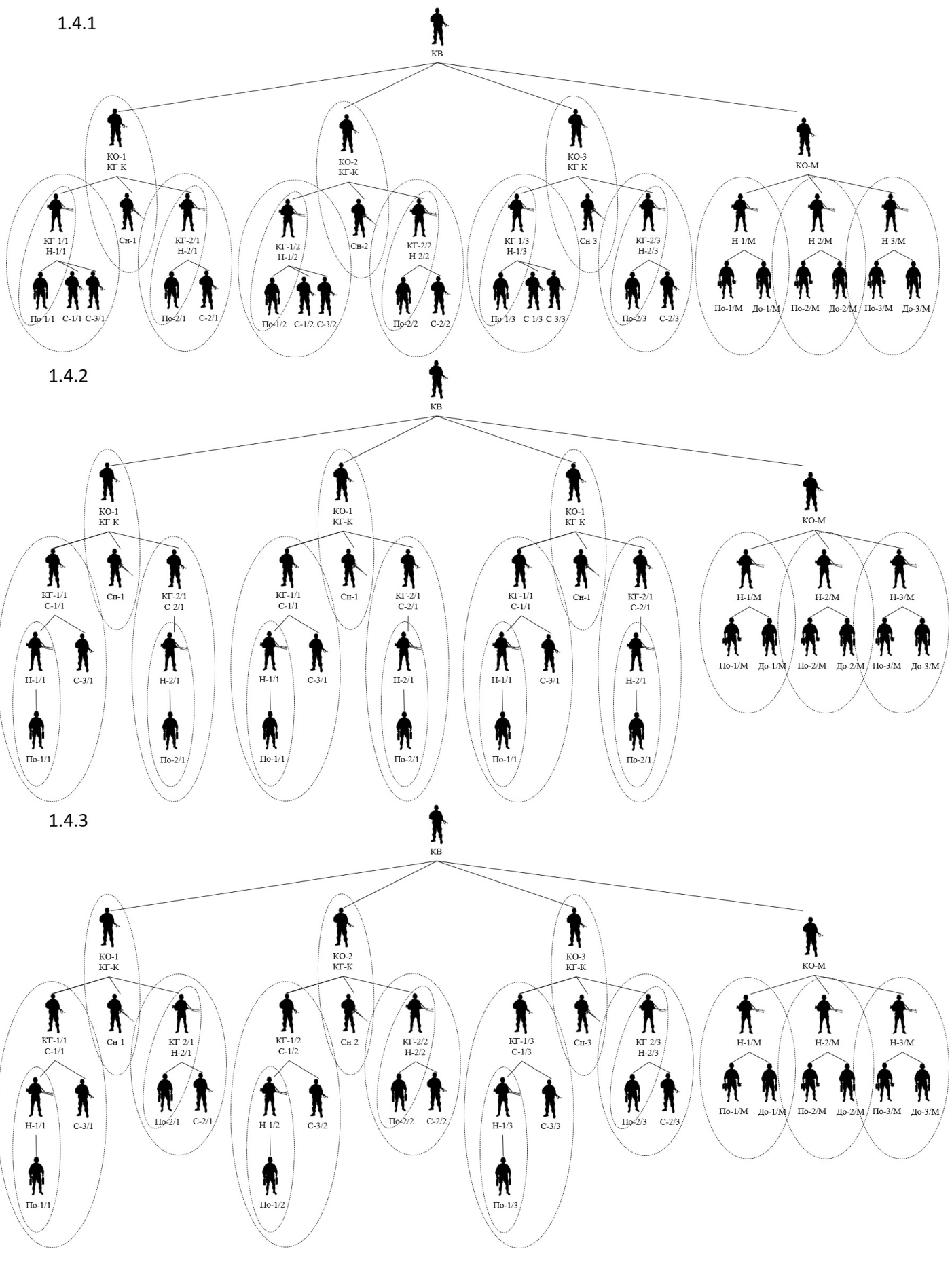

Figure 5: Model 1.4.1, Model 1.4.2 and Model 1.4.3

\section{MODEL 1.4.1}

Rifle section commanders are senior to two groups of three and four soldiers and one soldier. In this model, it is a sniper but it could be also and rifleman from one of the rifle sections groups. Group commanders are light machine-gunners. Group commanders are superior to an assistant, and two or one soldiers. Machine-gun section commander is senior to three machine-gun crews.

MODEL 1.4.2

The same organisation as in model 1.4.1 is modified by changing soldiers on the position of group commanders in rifle sections. Rifle section commanders are 
senior to two groups of three and four soldiers and one soldier. Group commanders are riflemen. Machine-gun section commander is senior to three machine-gun crews.

\section{MODEL 1.4.3}

Rifle section commanders are senior to two groups of three and four soldiers and one soldier. One group commander is a rifleman the second group commander is a light machine-gunner. Machine-gun section commander is senior to three machine-gun crews.

\section{Conclusions}

Researching and generalizing in this project it was formed nine models classified into four groups of model command organisation in a rifle platoon.

With these models of subordination, tasks can be divided into smaller groups that can work synchronously and following the obtained tasks in a larger space. Although there are more senior positions in the chain of command, they enable better control of the implementation of commands in the execution of the activities of the rifle sections.

Those models are formed to show how rifle platoon could be organised in a basic manner for general missions and tasks. This is basic for future research in which rifle platoon models of organisation will be optimised for specific situations.

\section{Acknowledgements}

This paper was written as part of the scientific research project funded by the Military Academy of the University of Defence in Belgrade, number: VADH/1/21-23 "Uticaj savremenog okruženja na izvođenje borbenih dejstava u urbanim sredinama" ("Influence of contemporary environment on the conduct of combat activities in urban spaces").

\section{References List}

[1] Združena operativna komanda Generalštaba Vojske Srbije. Doktrina komandovanja privremena. Belgrade. 2016.

[2] Komanda za obuku Generalštaba Vojske Srbije. Pravilo vojnik-odeljenje pešadije. Belgrade. 2016.

[3] Headquarters, Department of the Army. Army Leadership and the Profession. ADP 622 C1. 2019.

[4] Milan Đurović, at all. Rukovođenje i komandovanje. Beograd:Vojnoizdavački zavod. 1983.

[5] Komanda za obuku Generalštaba Vojske Srbije. Pravilo pešadijska četa-vod. Belgrade. 2016.

[6] Uprava pešadije Sektora za Kopnenu vojsku Generalštaba Vojske Jugoslavije. Pravilo puškomitraljez 7,62 mm M84. Beograd: Vojnoizdavački zavod. 1998.

[7] Uprava pešadije Zamenika generalštaba za KoV Generalštaba Oružanih snaga SFRJ Saveznog sekretarijata za narodnu odbranu. Pravilo mitraljez 7,62 mm M84. Beograd: Vojnoizdavački i novinski centar. 1989.

[8] Vinko Žnidaršič, Zoran Karavidić, Damir Projović and Dragan Stevanović. Analiza propisanih modela subordinacije u streljačkom odeljenju Vojske Srbije. Vojno delo, volume 71, issue 4, DOI: 10.5937/vojdelo1902192Z, 2019, pages 192-205.

[9] Vinko Žnidaršič, Zoran Karavidić. Modeli subordinacije u streljačkom odeljenju Vojske Srbije, Vojno delo, godina 71, broj 2, DOI: 10.5937/vojdelo1902192Z, 2019, pages 192-205.

[10] United States, Deparment of the Army, Headquarters. The Infantry Rifle Platoon and Squad (ATP 3-21.8, C1). Washington, DC, April 2016. Page 1-11. 